\author{
Zbigniew Zioło \\ Uniwersytet Pedagogiczny \\ im. Komisji Edukacji Narodowej \\ w Krakowie
}

\title{
Przedsiębiorczość jako czynnik rozwoju społeczno-gospodarczego układów przestrzennych
}

\author{
Entrepreneurship as a factor of the socio-economic development of spatial \\ systems
}

\begin{abstract}
Streszczenie
W pracy przyjęto założenie, że na rozwój procesów społeczno-gospodarczych układów przestrzennych zasadniczo wpływa poziom i jakość zasobów intelektualnych, które umożliwiają generowanie kapitału ludzkiego i społecznego, a także pobudzanie społecznych postaw przedsiębiorczości. Na tym tle szczególną uwagę zwrócono na: uwarunkowania kształtowania społecznych postaw przedsiębiorczości, wpływ potencjału ekonomicznego firm na aktywizację gospodarczą i powiązania rynkowe, relacje między różnymi kategoriami firm, ich własnością, rodzajem produkcji i zasięgami rynku oraz wpływ przedsiębiorczości na rozwój społeczno-gospodarczy i kulturowy, a także podstawowe uwarunkowania kształtowania przedsiębiorczości w układach przestrzennych.
\end{abstract}

\begin{abstract}
This study assumes that the development of socio-economic spatial systems is crucially influenced by the level and quality of intellectual resources that allow the generation of human and social capital, as well as the social stimulation of entrepreneurship. Against this background, particular attention has been paid to: factors shaping social entrepreneurship, the impact of the economic potential of the companies on the stimulation of economic and market relationships, arguments between different categories of companies, their property, the type of production and coverage of the market, as well as the impact of entrepreneurship on the socio-economic, cultural and fundamental determinants of entrepreneurship education in spatial systems.
\end{abstract}

Słowa kluczowe: przedsiębiorczość; rozwój społeczno-gospodarczy; układy przestrzenne Keywords: entrepreneurship; spatial systems; socio-economic development

\section{Wstęp}

Kształtujące się procesy globalizacji nasiliły tempo polaryzacji światowej przestrzeni w zakresie poziomu rozwoju społeczno-gospodarczego. W konsekwencji prowadzi to do różnicowania poziomu rozwoju różnej skali układów przestrzennych - od skali lokalnej po skalę krajową - oraz różnicowania poziomu i jakości życia. Na rozwój tych procesów zasadniczo wpływa poziom oraz jakość zasobów intelektualnych, które umożliwiają generowanie kapitału ludzkiego i społecznego, a także pobudzanie społecznych postaw przedsiębiorczości. W świetle przedstawionych przesłanek przedmiotem niniejszych rozważań jest analiza wpływu przedsiębiorczości, jako jednego z ważnych czynników, na rozwój społeczno-gospodarczy układów przestrzennych. 
Ta niezwykle aktualna problematyka badawcza rozpatrywana jest z różnych punktów widzenia, stąd konieczne wydaje się podejmowanie prób jej ujęć całościowych, które są niezbędne dla prowadzenia racjonalnej polityki rozwoju. Poszczególni autorzy głównie zwracają uwagę na: rolę kapitału ludzkiego w kształtowaniu postaw przedsiębiorczych - zwłaszcza w warunkach kształtowania gospodarki opartej na wiedzy (Bratnicki, Strużyna, 2001; Chojnicki, 2007; Zioło, Rachwał, 2008) i w warunkach nasilających się procesów globalizacji (Zioło, Rachwał, 2005, 2011; Wach, 2013), rolę jakości kapitału ludzkiego w rozwoju gospodarki globalnej (Grodzicki, 2003), wpływ kapitału ludzkiego na kształtowanie obszarów wiejskich (Kamińska, Heffner, 2010; Klepacki, Gołębiowska, 2005; Zioło, 2010), rolę edukacji w podnoszeniu jakości kapitału ludzkiego (Borowiec, 2007), wpływ przedsiębiorczości na rozwój regionalny (Kuciński, 2010; Kudełko, 2005, 2007; Malik, 2013) oraz znaczenie kapitału ludzkiego dla podnoszenie konkurencyjności przedsiębiorstw i efektywności pracy (Rybek, 2003; Szałkowski, 2007; Łukasiewicz, 2009).

\section{Rola społecznego potencjału przedsiębiorczości w układach przestrzennych}

W strategiach rozwoju społeczno-gospodarczego i kulturowego układów przestrzennych podstawowe znaczenie ma kształtowanie społecznego potencjału przedsiębiorczości. Wiele prac poświęconych tej problematyce nie uwzględnia faktu, że rozwój gospodarczy, społeczny i kulturowy nie następuje samoczynnie, przez decyzje polityczne, ale dokonują go konkretni przedsiębiorcy. Natomiast zadaniem polityków jest stworzenia najkorzystniejszych warunków do pobudzania i rozwoju działalności gospodarczej. Konkurencyjność układów przestrzennych jest bowiem funkcją konkurencyjnych przedsiębiorców, którzy zarządzają różnego rodzaju podmiotami gospodarczymi i instytucjami zlokalizowanymi na ich terenie. Dlatego ważnym zagadnieniem jest systematyczne pogłębianie badań dotyczących problematyki funkcjonowania oraz kształtowania przedsiębiorczości, jako szczególnie ważnych czynników aktywizowania rozwoju gospodarczego, społecznego i kulturowego układów przestrzennych. Podstawowe znaczenie w tym zakresie ma zatem dbanie o budowanie autorytetu społecznego przedsiębiorcy, który rozwijając własną działalność gospodarczą, dzięki różnorodnym powiązaniom, przyczynia się do wzrostu ekonomicznego. Wiele nieporozumień w ocenie przedsiębiorcy, także ze strony instytucji państwowych, wynika z braku pogłębionej wiedzy ekonomicznej. Przedsiębiorca bowiem działa zgodnie z regułami mikroekonomicznymi, których celem jest osiąganie maksymalnych zysków oraz obniżanie kosztów produkcji i usług. Natomiast reguły mezoekonomiczne, którymi rządzą się układy lokalne i regionalne, przede wszystkim zwracają uwagę na osiągania jak największych korzyści, głównie przez zwiększanie strumieni finansowych płynących do samorządowych układów lokalnych i regionalnych. Generuje to konflikty interesów, które należy rozwiązywać w drodze negocjacji, zwracając uwagę na obopólne korzyści.

Ważnym zadaniem władz samorządowych i krajowych jest stwarzanie korzystnych warunków dla zwiększania potencjału przedsiębiorczości w układach przestrzennych w wyniku prowadzenia odpowiedniej polityki gospodarczej, społecznej i kulturowej. W budowie strategii ich rozwoju konieczne jest uwzględnienie nie tylko wąsko pojętych czynników ekonomicznych, lecz także czynników społecznych i kulturowych. W tym zakresie ważnym zagadnieniem staje się również tworzenie zaufania społeczeństwa do elit władzy samorządowej i państwowej oraz dbałość o podnoszenie poziomu kulturowego i jakości życia społeczeństwa. Społeczeństwo o wyższym poziomie kulturowym jest bardziej otwarte na innowacje i zwiększa swoją odpowiedzialność za kierunki i nasilanie procesów rozwoju (ryc. 1).

Znaczący wpływ na jakość działalności gospodarczej, społecznej i instytucjonalnej ma poziom wykształcenia i kwalifikacji społeczeństwa, który stanowi podstawowy zasób potencjału przedsiębiorczości. Poszczególne typy wykształcenia spełniają różne funkcje. Szkolnictwo 
Ryc. 1. Społeczny potencjał przedsiębiorczości w układach przestrzennych

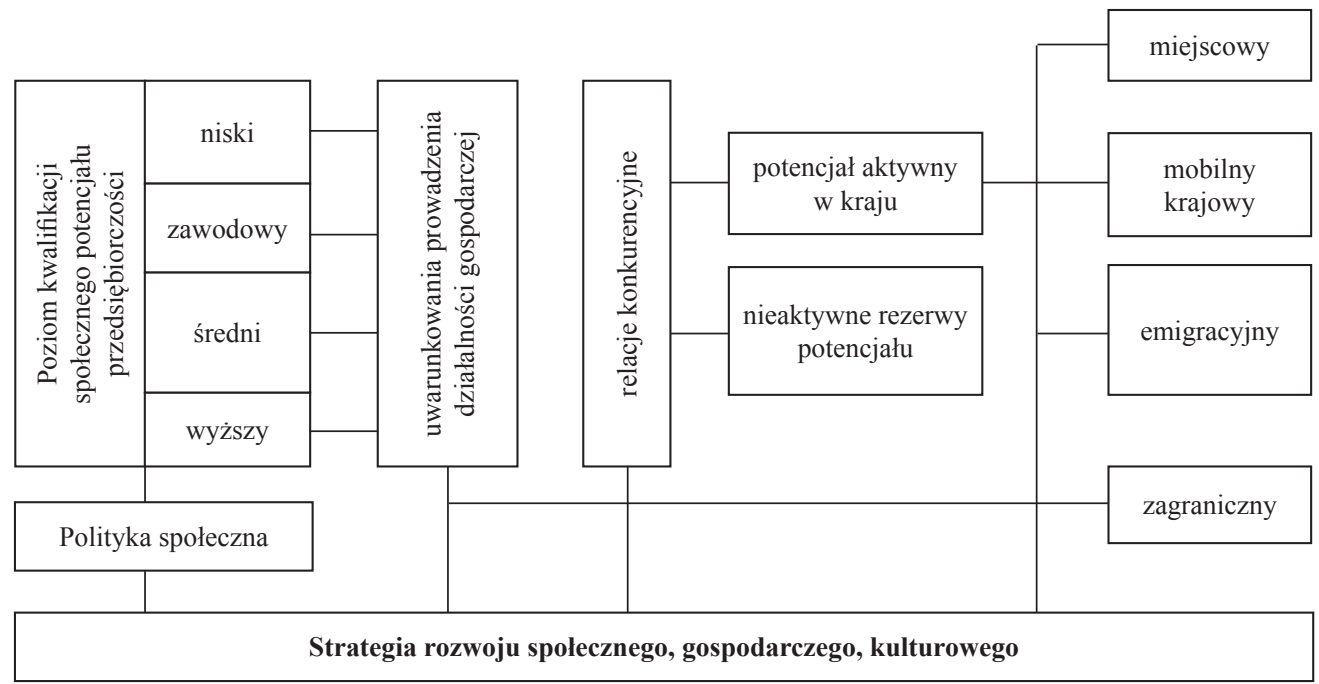

Źródło: opracowanie własne.

zawodowe ma przygotować wykwalifikowane kadry pracownicze do wykonywania określonych prac. W procesie ich przygotowania ważne są pewne zasoby wiedzy teoretycznej i ogólnej oraz umiejętności praktyczne. Upadek tej formy kształcenia oraz likwidowanie szkół zawodowych obecnie odbija się negatywnie na możliwościach rozwoju przedsiębiorczości, co wynika z braku odpowiednich fachowców. Ważnym zadaniem pozostaje więc odbudowa tego typu szkolnictwa zawodowego - wcześniej zniszczonego. Potrzebę tę rozumieją nieliczne samorządy lokalne, które organizują na swoim terenie szkolnictwo zawodowe, często w powiązaniu z przedsiębiorstwami. Umożliwiają one młodzieży zdobycie odpowiedniego wykształcenia, pozwalającego na podnoszenie jej konkurencyjności na krajowym i międzynarodowym rynku pracy.

Podobnie ograniczanie edukacji na poziomie technicznym wpłynęło na obecne braki kadrowe w przedsiębiorstwach, które wraz z wychodzeniem gospodarki z kryzysu będą się jeszcze pogłębiać. Próbuje się je uzupełniać przez wyższe wykształcenie licencjackie czy inżynierskie lub akademickie, wymagając od uczelni kształcenia praktycznego. Potrzeby kadrowe realizowały wcześniej średnie szkoły techniczne i policealne, mające określone zaplecze dydaktyczne i często powiązania z potrzebami miejscowych przedsiębiorstw. Zamiast likwidować średnie kształcenie techniczne należało podnieść jego rangę do inżynierskiego, ponieważ obecne studia inżynierskie w znacznym stopniu nawiązują do poprzedniego kształcenia policealnego. Wynika stąd pilna potrzeba przebudowy systemu szkolnictwa, które przyczyniać się będzie także do rozwijania przedsiębiorczości ${ }^{1}$.

\footnotetext{
${ }^{1}$ Osoby mniej rozumiejące procesy rozwoju gospodarczego i cywilizacyjnego oraz funkcje systemu edukacyjnego uważają, że szkoda nakładów na edukację, ponieważ wykształcona kadra będzie emigrowała zagranicę. Dzieje się tak dlatego, że układy przestrzenne nie stwarzają możliwości realizacji aspiracji i planów życiowych - zwłaszcza młodzieży - ani warunków godziwej egzystencji. Wzrost potencjału przedsiębiorczości jest poważnym zadaniem dla przedstawicieli różnych szczebli władz samorządowych i państwowych oraz władz ustawodawczych. Równocześnie należy przyjąć, że procesy migracyjne nie będą się osłabiać i zachodzi pytanie, czy emigrować mają ludzie bez kwalifikacji zawo-
} 
Społeczny potencjał przedsiębiorczości jest jednym z ważniejszych uwarunkowań prowadzenia i rozwijania działalności gospodarczej. Równocześnie należy przyjąć, że wraz z pobudzaniem wzrostu gospodarczego coraz silniej będzie się pojawiać konkurowanie o odpowiednio przygotowane kadry pracownicze. Przejawiać się to będzie m.in. w nasileniu rekrutacji określonych grup pracowniczych na rynki krajowe i zagraniczne, prowadzonych przez wyspecjalizowane firmy.

W wyniku tego procesu część potencjalnych pracowników emigruje i będzie nadal emigrować zagranicę, a tylko niektórzy zostaną w kraju. Istniejące dotąd nieaktywne zasoby potencjału przedsiębiorczości, wraz ze stwarzaniem korzystniejszych warunków do prowadzenia działalności, mogą podejmować swoją działalność na terenie kraju lub stanowić pewną rezerwę dla dalszego rozwoju. Krajowy potencjał zasobów ludzkich może mieć szansę podjęcia pracy i doskonalenia zawodowego na miejscowym albo krajowym rynku pracy. Podobnie mają okazję realizować się nieaktywne do tej pory rezerwy potencjału, które mogą szukać pracy na miejscowych, krajowych czy międzynarodowych rynkach pracy.

Znajomość tego procesu jest niezbędna dla właściwego wspierania procesów rozwoju społeczno-gospodarczego i kulturowego w określonych układach przestrzennych. Celem odpowiednich działań może być dążenie do wykorzystania własnego potencjału przedsiębiorczego oraz - dzięki podniesieniu atrakcyjności danego układu przestrzennego - spowodowanie napływu do pracy zasobów ludzkich z otoczenia, mających odpowiedni potencjał przedsiębiorczości.

\section{Typy przedsiębiorstw}

Potencjał przedsiębiorczości społecznej umożliwia kreowanie firm zróżnicowanych pod względem potencjału produkcyjnego i usługowego, rodzajów działalności gospodarczej, a także rozwijania działalności określonych instytucji. Mogą to być firmy o niewielkim potencjale ekonomicznym, tzw. mikrofirmy, firmy małe lub firmy duże (ryc. 2).

Dla racjonalnego zarządzania bardzo ważnym elementem jest struktura własności przedsiębiorstw, ponieważ umożliwia ona stosowanie różnych instrumentów pobudzających ich rozwój. Wśród nich mogą występować firmy: państwowe, państwowych osób prawnych, komunalne, prywatne, zagraniczne i z kapitałem mieszanym. Największy, bezpośredni wpływ państwa na procesy działalności zaznacza się w firmach państwowych ${ }^{2}$ i państwowych osób prawnych. Mają one strategiczne znaczenie dla państwa, stąd wiele z nich pozostaje w gestii rządu.

dowych, czy osoby odpowiednio przygotowane do osiągania sukcesów zawodowych zagranicą. Ważne jest pytanie, co zrobić, aby po zdobyciu nowych umiejętności ludzie ci powrócili do kraju i przyczyniali się do rozwijania działalności gospodarczej.

${ }^{2} \mathrm{~W}$ procesie ich działalności może się pojawiać wiele nieprawidłowości związanych z nieracjonalną polityką kadrową, w której może dominować klucz przynależności partyjnej nad kwalifikacjami merytorycznymi. W wyniku tego może dochodzić do złego zarządzania oraz obciążania firm niekompetentnymi członkami rad nadzorczych i działaczami społecznymi, co sprzyja rozwijaniu korupcji. Przykładem tego jest wiele nieprawidłowości w działalności polskiego górnictwa węglowego, kolei, budowy infrastruktury kolejowej, drogowej czy autostrad, co często wiąże się z brakiem kompetencji członków władz krajowych (np. A. Stankiewicz, Ziemia porzucona. Górnicy wystawiają rządowi rachunek. Rzeczpospolita, 14 stycznia 2015 r.). Nawiązuje do tego uwaga A. Kuklińskiego (1995: 40), który przyjmuje, ,że główną stratą związaną z pełnym członkostwem Polski, jest ograniczenia naszej suwerenności gospodarczej i w pewnym stopniu politycznej. Uważa, że ograniczony zakres suwerenności będzie również ograniczonym zakresem popełniania błędów oraz podejmowania decyzji, które nie zawsze myślą o dobru Rzeczpospolitej”. 
Ryc. 2. Typy przedsiębiorstw

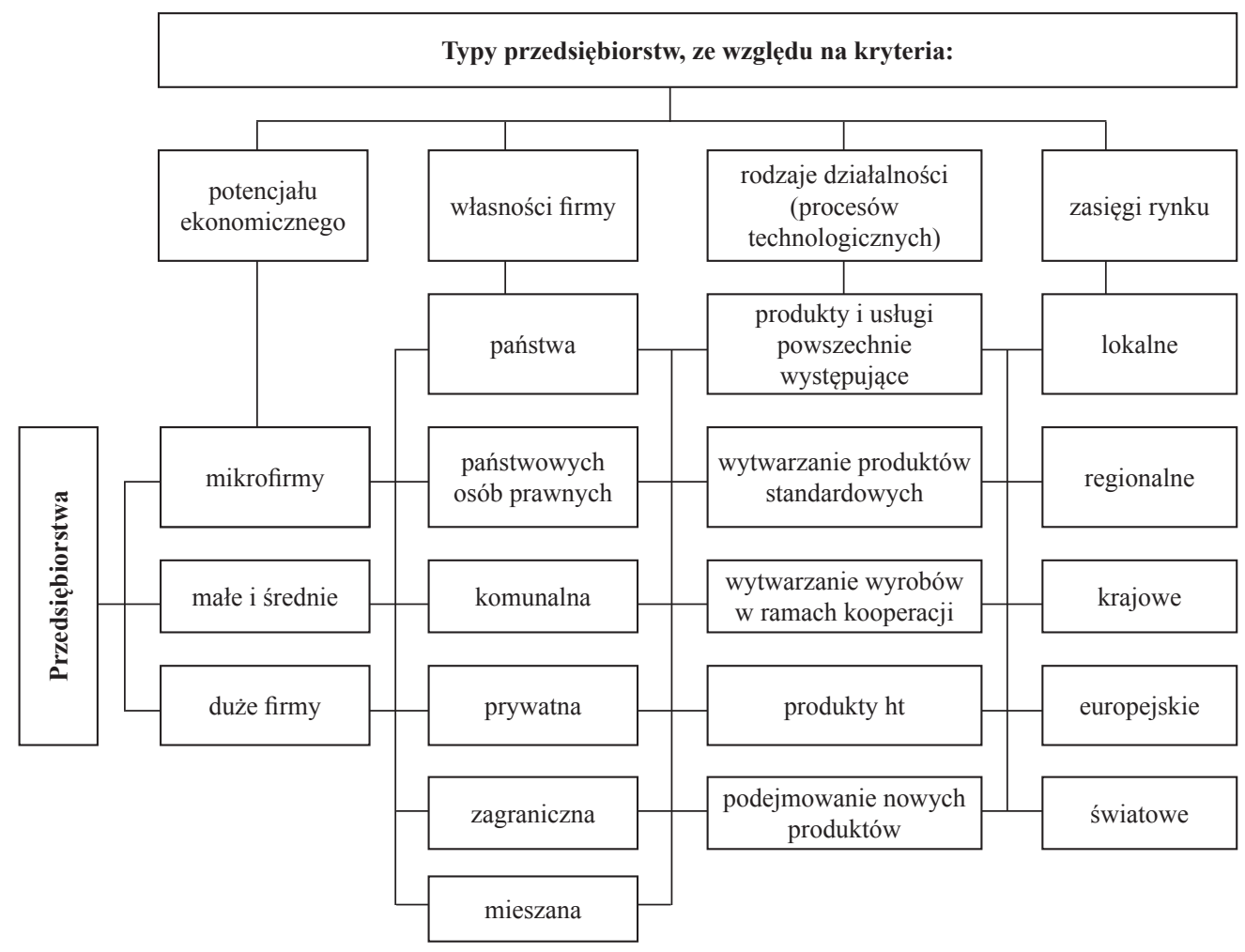

Źródło: opracowanie własne.

Firmy komunalne podlegają organom samorządowym i spełniają określone zadania na terenie działalności danego układu samorządowego.

Firmy prywatne rządzą się według reguł mikroekonomicznych, zgodnie z którymi właściciel na własne ryzyko podejmuje samodzielne decyzje dotyczące kierunków działalności firmy.

Firmy zagraniczne zarządzane są przez zarządy zlokalizowane na terenie innych krajów. Realizują one zadania wynikające $\mathrm{z}$ potrzeb kapitału zagranicznego, który w różnym stopniu może uwzględniać interesy danego państwa. Przedsiębiorstwa zagraniczne samodzielnie decydują o rozmiarach produkcji, poziomie zatrudnienia, przenoszeniu działalności do innych regionów czy krajów. Na ich decyzje może wpływać dążenie do obniżania kosztów pracy, a odpowiednie porozumienia z rządem mogą wpływać na aktywizację rynku pracy kraju macierzystego, zwłaszcza w okresie kryzysu, czy zmianę rynku zbytu, np. w wyniku embarga nakładanego przez grupę krajów lub dany kraj. Wpływa to na rozmiary produkcji oraz kierunki zaopatrzenia i eksportu.

W firmach o własności mieszanej głównie przeważają decyzje największego udziałowca lub dominującej grupy udziałowców.

Władze danych układów przestrzennych - w zależności od wielkości potencjału ekonomicznego firmy i jej własności - mogą podejmować indywidualne decyzje w zakresie pobudzania rozwoju danych przedsiębiorstwa, najczęściej przez ulgi przyznawane np. w specjalnych stre- 
fach ekonomicznych, a także zamówienia publiczne, np. dla instytucji publicznych, wyposażenia armii lub służb mundurowych.

Poszczególne firmy różnicują się także w zakresie rodzajów działalności produkcyjnej, produkcyjno-usługowej czy usługowej. Mogą one wytwarzać produkty:

- mające powszechne zastosowanie w przedsiębiorstwach, instytucjach czy gospodarstwach domowych,

- standardowe dla wybranych typów odbiorców,

- wytwarzane w ramach powiązań kooperacyjnych dla różnego typu firm krajowych i zagranicznych,

- nowoczesne - wysokiej technologii,

- nowe, przenoszone najczęściej z krajów o wyższym poziomie rozwoju.

Podstawowym elementem rozwoju działalności gospodarczej jest jakość i chłonność rynków na oferowane produkty, które kształtują się w drodze relacji konkurencyjnych. Zasięgi rynków mogą być bardzo zróżnicowane oraz obejmować rynki lokalne, regionalne, krajowe i światowe. Pozycję produktu na konkurencyjnym rynku wyznacza jego jakość i dodatkowe cechy, takie jak: długość okresu gwarancyjnego, cena, dostępność i możliwości serwisu. Rozmiary chłonności rynku zmieniają się głównie pod wpływem zmian zasobów finansowych ludności oraz instytucji i przedsiębiorstw, które mają określone możliwości finansowe zakupów danej liczby produktów i usług.

Polityka państwa może się przejawiać we wspieraniu rozwoju wybranych rodzajów działalności gospodarczej albo ich osłabianiu, w drodze generowania instrumentów bezpośredniego lub pośredniego oddziaływania. Mogą one wpłynąć na zwiększenie bądź ograniczenie zapotrzebowania na oferowane dobra, z jednej strony np. przez wzrost akcyzy lub podatków, a $\mathrm{z}$ drugiej - przez dotowanie produkcji określonych wyrobów, pomoc finansową w rozwijaniu działalności gospodarczej, tworzenie zasobów kapitału wysokiego ryzyka, a także różne formy zwalniania z opłat i zamówienia publiczne.

\section{Relacje między wyróżnionymi cechami firm}

Funkcjonowanie firm i rozwój działalności gospodarczej dokonują się w złożonych warunkach, które wynikają z relacji zachodzących między omówionymi wyżej cechami (tab. 1). W strukturze firm o określonym potencjale ekonomicznym zaznaczają się różnego typu powiązania w zakresie dostaw surowcowych, powiązań kooperacyjnych, działalności usługowej, zagospodarowania odpadów produkcyjnych itp. Zagadnienia te ilustrują relacje wewnętrzne zachodzące między ich potencjałem ekonomicznym $-\left[\mathrm{x}^{\mathrm{x}}{ }_{\mathrm{ij}}\right]$.

Podobne relacje występują między firmami reprezentującymi różne formy własności $-\left[\mathrm{y}^{\mathrm{y}}{ }_{\mathrm{ij}}\right]$. W wyniku powiązań technologicznych, finansowych i kapitałowych mogą one utrzymywać powiązania produkcyjne, usługowe, finansowe czy kapitałowe. Na skutek działań prywatyzacyjnych mogą także zmieniać właściciela - przez ich zakup, przejęcie czy konsolidację i tworzyć bardziej złożone struktury gospodarcze. Odnosi się to zwykle do firm, które tracą dotychczasowy rynek w związku z obniżeniem konkurencyjności oferowanych produktów. Dokonuje się to z reguły w wyniku braku nowych inwestycji i opóźnień technologicznych, co w konsekwencji - przy nieposiadaniu własnego kapitału - przyczynia się do ograniczania lub utraty ich płynności finansowej.

Utrzymanie pozycji na konkurencyjnym rynku wymaga stałego podnoszenia jakości i nowoczesności oferowanych produktów. Niezbędne są w tym zakresie odpowiednie nakłady inwestycyjne na zakup nowych technologii, maszyn i urządzeń, by podjąć nową lub bardziej zaawansowaną produkcję czy oferować lepsze usługi $-\left[\mathrm{w}_{\mathrm{ij}}^{\mathrm{w}}\right]$. Mogą one prowadzić do zmian 
Tab. 1. Relacja między wyróżnionymi cechami firm

\begin{tabular}{|c|c|c|c|c|c|c|c|c|c|c|c|c|c|c|}
\hline \multicolumn{3}{|c|}{ Typy przedsiębiorstw } & $X_{1}$ & ... & $\mathbf{X}_{3}$ & $Y_{1}$ & ... & $Y_{6}$ & $\mathrm{~W}_{1}$ & $\ldots$ & $W_{5}$ & $\mathbf{P}_{1}$ & ... & $\mathbf{P}_{5}$ \\
\hline \multirow{3}{*}{$\begin{array}{c}\text { Potencjału } \\
\text { ekonomicznego }\end{array}$} & mikrofirmy & $\mathrm{X}_{1}$ & \multirow{3}{*}{\multicolumn{3}{|c|}{$\mathrm{x}^{\mathrm{x}}{ }_{\mathrm{ij}}$}} & \multirow{3}{*}{\multicolumn{3}{|c|}{$\mathrm{x}_{\mathrm{ij}}^{\mathrm{y}}$}} & \multirow{3}{*}{\multicolumn{3}{|c|}{$\mathrm{x}^{\mathrm{w}}{ }_{\mathrm{ij}}$}} & \multirow{3}{*}{\multicolumn{3}{|c|}{$\mathrm{x}_{\mathrm{ij}}$}} \\
\hline & małe i średnie & $X_{2}$ & & & & & & & & & & & & \\
\hline & duże firmy & $X_{3}$ & & & & & & & & & & & & \\
\hline \multirow{6}{*}{$\begin{array}{l}\text { Wlasności } \\
\text { firmy }\end{array}$} & państwa & $\mathrm{Y}_{1}$ & \multirow{6}{*}{\multicolumn{2}{|c|}{$\mathrm{y}^{\mathrm{x}}{ }_{\mathrm{ij}}$}} & & \multirow{6}{*}{\multicolumn{2}{|c|}{$\mathrm{y}^{\mathrm{y}}{ }_{\mathrm{ij}}$}} & & \multirow{6}{*}{\multicolumn{3}{|c|}{$\mathrm{y}^{\mathrm{w}}{ }_{\mathrm{ij}}$}} & \multirow{6}{*}{\multicolumn{2}{|c|}{$\mathrm{y}^{\mathrm{p}}{ }_{\mathrm{i}}$}} & \\
\hline & $\begin{array}{l}\text { państwowych osób } \\
\text { prawnych }\end{array}$ & $\mathrm{Y}_{2}$ & & & & & & & & & & & & \\
\hline & komunalna & $\mathrm{Y}_{3}$ & & & & & & & & & & & & \\
\hline & prywatna & $\mathrm{Y}_{4}$ & & & & & & & & & & & & \\
\hline & zagraniczna & $\mathrm{Y}_{5}$ & & & & & & & & & & & & \\
\hline & mieszana & $\mathrm{Y}_{6}$ & & & & & & & & & & & & \\
\hline \multirow{5}{*}{$\begin{array}{c}\text { Rodzaje } \\
\text { działności } \\
\text { (procesów } \\
\text { technologicz- } \\
\text { nych) }\end{array}$} & $\begin{array}{l}\text { produkty i usługi } \\
\text { powszechnie } \\
\text { występujące }\end{array}$ & $\mathrm{W}_{1}$ & \multirow{5}{*}{\multicolumn{2}{|c|}{$\mathrm{w}_{\mathrm{ij}}^{\mathrm{x}}$}} & & \multirow{5}{*}{\multicolumn{2}{|c|}{$\mathrm{w}^{\mathrm{y}}{ }_{\mathrm{ij}}$}} & & \multirow{5}{*}{\multicolumn{2}{|c|}{$\mathrm{w}^{\mathrm{w}}{ }_{\mathrm{ij}}$}} & & \multirow{5}{*}{\multicolumn{2}{|c|}{$\mathrm{w}^{\mathrm{P}}$}} & \\
\hline & $\begin{array}{l}\text { wytwarzanie } \\
\text { produktów } \\
\text { standardowych } \\
\end{array}$ & $\mathrm{W}_{2}$ & & & & & & & & & & & & \\
\hline & $\begin{array}{l}\text { wytwarzanie } \\
\text { wyrobów w ramach } \\
\text { kooperacji }\end{array}$ & $\mathrm{W}_{3}$ & & & & & & & & & & & & \\
\hline & produkty ht & $\mathrm{W}_{4}$ & & & & & & & & & & & & \\
\hline & $\begin{array}{l}\text { podejmowanie } \\
\text { nowych produktów }\end{array}$ & $\mathrm{W}_{5}$ & & & & & & & & & & & & \\
\hline \multirow{5}{*}{ Zasięgi rynku } & lokalne & $\mathrm{P}_{1}$ & \multirow{5}{*}{\multicolumn{2}{|c|}{$\mathrm{p}^{\mathrm{x}}{ }_{\mathrm{ij}}$}} & & \multirow{5}{*}{\multicolumn{3}{|c|}{$\mathrm{p}^{\mathrm{y}}{ }_{\mathrm{ij}}$}} & \multirow{5}{*}{\multicolumn{3}{|c|}{$\mathrm{p}^{\mathrm{w}}{ }_{\mathrm{ij}}$}} & \multirow{5}{*}{\multicolumn{2}{|c|}{$\mathrm{p}^{\mathrm{p}}{ }_{\mathrm{ij}}$}} & \\
\hline & regionalne & $\mathrm{P}_{2}$ & & & & & & & & & & & & \\
\hline & krajowe & $\mathrm{P}_{3}$ & & & & & & & & & & & & \\
\hline & europejskie & $\mathrm{P}_{4}$ & & & & & & & & & & & & \\
\hline & światowe & $\mathrm{P}_{5}$ & & & & & & & & & & & & \\
\hline
\end{tabular}

Źródło: opracowanie własne.

rodzajów produkcji, najczęściej od artykułów tradycyjnych powszechnego zastosowania do artykułów nowoczesnych.

Rozwój działalności musi nawiązywać do poszukiwania możliwości pogłębiania albo rozszerzania zasięgu istniejących rynków zbytu na oferowane produkty czy usługi oraz zdobywania nowych rynków. Dokonuje się to zwykle przez oferowanie bardziej konkurencyjnych i nowoczesnych produktów - $\left[\mathrm{p}^{\mathrm{p}}{ }_{\mathrm{ij}}\right]$.

W procesie funkcjonowania i rozwoju działalności przedsiębiorstw między wyróżnionymi kategoriami cech zachodzą różnorodne relacje mające na celu podnoszenie pozycji konkurencyjnej produktów, osiągnięcie odpowiednich zysków i obniżenie kosztów. Potencjał ekonomiczny firm w znacznym stopniu zależy od typu własności $\left[\mathrm{x}_{\mathrm{ij}}{ }\right.$ oraz wpływa na możliwości wytwarzania danych kategorii produktów $\left[\mathrm{x}^{\mathrm{w}}{ }_{\mathrm{ij}}\right]$, co z kolei stwarza określone szanse ich zachowań na konkurencyjnym rynku $\left[\mathrm{x}^{\mathrm{p}}{ }_{\mathrm{ij}}\right]$. Mikrofirmy o niewielkim potencjale kapitałowym, należące do prywatnych właścicieli, najczęściej podejmują działalność ograniczającą się do 
rynku lokalnego. W wyniku niewielkich zasobów finansowych oraz niepodejmowania ryzyka w zakresie ich pozyskania od instytucji finansowych mają one zwykle ograniczone możliwości rozwijania nowoczesnej produkcji. Ponadto, nierzadko muszą konkurować z większymi firmami oferującymi podobny i często tańszy produkt, na który znajdują zapotrzebowanie. Szczególnie nasila się to w okresie pogarszania się sytuacji gospodarczej, prowadzącej do zmniejszania się zasobów finansowych ludności i instytucji, a w konsekwencji - do kurczenia się rynku przez ograniczanie ich potrzeb. Często większe firmy, dysponujące własnymi zasobami finansowymi, mogą znacząco obniżać ceny, przyczyniając się do upadku przedsiębiorstw czy ich przejęcia, by następnie je wzmocnić i wyrównać początkowo poniesione straty.

W innej sytuacji są duże korporacje międzynarodowe, dysponujące znacznymi zasobami kapitałowymi, wśród których - zwłaszcza w okresie kryzysu - nasilają się relacje konkurencyjne prowadzące do ograniczania wielkości produkcji a często także do zmian właścicielskich ${ }^{3}$.

W procesie tym zaznaczają się określone relacje aktywne i pasywne zachodzące między wyróżnionymi cechami. Relacje aktywne przedstawiają wiersze tabeli, w których np. własność firmy $\left(\mathrm{Y}_{\mathrm{i}}\right)$ w określonym stopniu wpływa na potencjał ekonomiczny $\left(\mathrm{X}_{\mathrm{j}}\right)$. Stwarza to często odmienne możliwości w zakresie ich rozwoju - $\left[\mathrm{y}^{\mathrm{x}}{ }_{\mathrm{ij}}\right]$, a także różne możliwości podejmowania wytwarzania nowych produktów $\left[\mathrm{y}^{\mathrm{w}}{ }_{\mathrm{ij}}\right]$ oraz zachowań na rynku $\left[\mathrm{y}_{\mathrm{ij}}{ }_{\mathrm{ij}}\right.$.

Podobnie firmy reprezentujące różne rodzaje produkcji są silnie związane z wielkością firmy $\left[\mathrm{w}^{\mathrm{x}}{ }_{\mathrm{ij}}\right]$, jej własnością $\left[\mathrm{w}_{\mathrm{ij}}^{\mathrm{y}}\right]$ oraz rynkami $\left[\mathrm{w}_{\mathrm{ij}}^{\mathrm{p}}\right]$.

Różne możliwości zachowań rynkowych mają firmy zróżnicowane pod względem potencjału ekonomicznego $\left[\mathrm{p}^{\mathrm{x}}{ }_{\mathrm{ij}}\right]$, posiadające odmienną formę własnością $\left[\mathrm{p}_{\mathrm{ij}}^{\mathrm{y}}\right.$ ] i oferujące określone produkty $\left[\mathrm{p}^{\mathrm{w}}{ }_{\mathrm{ij}}\right]$.

Relacje pasywne określają kolumny tabeli, np. na potencjał ekonomiczny firmy wpływają: własność firmy $\left[\mathrm{y}^{\mathrm{x}}{ }_{\mathrm{ij}}\right]$, rodzaj działalności $\left[\mathrm{w}^{\mathrm{x}}{ }_{\mathrm{ij}}\right]$ i zasięg rynku $\left[\mathrm{p}^{\mathrm{x}}{ }_{\mathrm{ij}}\right]$, podobnie na zasięgi rynku oddziałuje: potencjał ekonomiczny firmy $\left[\mathrm{x}^{\mathrm{p}}{ }_{\mathrm{ij}}\right]$, własność firmy $\left[\mathrm{y}_{\mathrm{ij}}\right]$ i rodzaj działalności $\left[\mathrm{w}^{\mathrm{p}}{ }_{\mathrm{ij}}\right]$.

\section{Wpływ przedsiębiorczości na rozwój społeczno-gospodarczy i kulturowy układów przestrzennych}

Rozwój społeczno-gospodarczy i kulturowy danych układów przestrzennych zasadniczo związany jest ze społecznymi postawami przedsiębiorczymi i potencjałem ekonomicznym firm. W różnej skali układów przestrzennych dokonuje się to zwykle przez aktywizację określonych kategorii zasobów wewnętrznych i zewnętrznych, przy racjonalnym ich wykorzystaniu. Efekty tych działań przejawiają się we wzroście potencjału ekonomicznego układów przestrzennych, stagnacji lub recesji (ryc. 3). W procesie tym podstawowe znaczenie mają kryteria ekonomicznej efektywności, które realizują się w wyniku jakości i poziomu produkcji oraz zwiększaniu chłonności rynku danego układu przestrzennego i jego otoczenia. Dzięki odpowiedniej polityce ważnym kryterium działalności, obok efektywności ekonomicznej, mogą być także kryteria efektywności społecznej i kulturowej.

Aktywizacja zasobów pracy dokonuje się na skutek wzrostu zatrudnienia i wpływa na ograniczanie bezrobocia, podnoszenie jakości i przemiany kwalifikacji zawodowych, które wymagają rozwoju edukacji zawodowej. Prowadzi to do łagodzenia zjawisk patologii społecznej oraz zmniejszania rozmiarów świadczeń społecznych.

\footnotetext{
${ }^{3}$ Przykładem tego może być znaczące obniżenie cen ropy przez kraje OPEC. Zgromadzony wcześniej przez nich kapitał pozwala obecnie na obniżenie ceny, by w ten sposób obniżyć pozycję konkurencyjną ropy otrzymywanej w Stanach Zjednoczonych z łupków. Zwłaszcza, że koszty eksploatacji ropy z łupków są ok. ośmiokrotnie wyższe od kosztów eksploatacji ropy w Arabii Saudyjskiej.
} 
Ryc. 3. Wpływ przedsiębiorczości na rozwój społeczno-gospodarczy i kulturowy układów przestrzennych

\begin{tabular}{|c|c|c|c|c|}
\hline \multicolumn{2}{|c|}{ Przedsiębiorczość } & \multicolumn{2}{|c|}{ Kryteria ekonomicznej efektywności } & \\
\hline \multirow{25}{*}{ 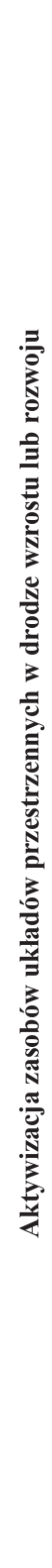 } & \multirow{3}{*}{ pracy } & wzrost zatrudnienia & ograniczanie bezrobocia & \multirow{25}{*}{ 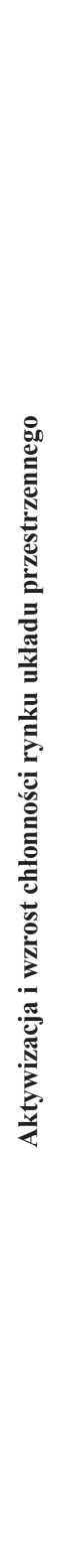 } \\
\hline & & $\begin{array}{l}\text { podnoszenie jakości, przemiana } \\
\text { kwalifikacji zawodowych }\end{array}$ & $\begin{array}{c}\text { zmniejszenie } \\
\text { świadczeń społecznych }\end{array}$ & \\
\hline & & ograniczenie zjawisk patologicznych & $\begin{array}{l}\text { rozwój edukacji } \\
\text { zawodowej }\end{array}$ & \\
\hline & \multirow{10}{*}{ finansowych } & rozbudowa działalności firmy & \multirow{2}{*}{$\begin{array}{l}\text { majątek układu } \\
\text { przestrzennego }\end{array}$} & \\
\hline & & $\begin{array}{c}\text { nowe inwestycje (komplementarne, } \\
\text { towarzyszące) }\end{array}$ & & \\
\hline & & \multirow{2}{*}{ zagospodarowanie zysków } & $\begin{array}{c}\text { w układzie } \\
\text { przestrzennym }\end{array}$ & \\
\hline & & & $\begin{array}{c}\text { wyprowadzenia poza } \\
\text { układ }\end{array}$ & \\
\hline & & \multirow{3}{*}{$\begin{array}{l}\text { wzrost dochodów gospodarstw } \\
\text { domowych }\end{array}$} & konsumpcja & \\
\hline & & & inwestycje & \\
\hline & & & oszczędności & \\
\hline & & \multirow{2}{*}{$\begin{array}{c}\text { aktywizacja istniejących zasobów } \\
\text { finansowych }\end{array}$} & $\begin{array}{l}\text { gospodarstw } \\
\text { domowych }\end{array}$ & \\
\hline & & & $\begin{array}{l}\text { przedsiębiorstw } \\
\text { i instytucji }\end{array}$ & \\
\hline & & $\begin{array}{l}\text { zasilanie budżetów (krajowego, } \\
\text { samorządowych) }\end{array}$ & $\begin{array}{l}\text { zwiększenie możliwości } \\
\text { inwestowania }\end{array}$ & \\
\hline & \multirow{4}{*}{$\begin{array}{c}\text { struktur } \\
\text { społecznych }\end{array}$} & nowe rynki pracy & $\begin{array}{c}\text { zagospodarowanie } \\
\text { zasobów ludzkich }\end{array}$ & \\
\hline & & $\begin{array}{c}\text { podnoszenie atrakcyjności układu } \\
\text { przestrzennego dla generowanie rozwoju }\end{array}$ & $\begin{array}{c}\text { napływ zewnętrznych } \\
\text { czynników rozwoju } \\
\text { (kapitału, pracy) }\end{array}$ & \\
\hline & & wzrost aspiracji społecznych & \multirow{10}{*}{$\begin{array}{l}\text { podnoszenie poziomu } \\
\text { kulturowego i cywi- } \\
\text { lizacyjnego układów } \\
\text { przestrzennych }\end{array}$} & \\
\hline & & rozwijanie zasobów intelektualnych & & \\
\hline & \multirow{5}{*}{$\begin{array}{c}\text { wdrażanie } \\
\text { nowych } \\
\text { wzorców } \\
\text { zachowań } \\
\text { cywilizacyjnych }\end{array}$} & wzrost kapitału ludzkiego & & \\
\hline & & wzrost kapitału społecznego & & \\
\hline & & nowe potrzeby kulturowe & & \\
\hline & & instytucje, obiekty & & \\
\hline & & nowe formy spędzania wolnego czasu & & \\
\hline & & $\begin{array}{l}\text { racjonalne wykorzystanie zasobów } \\
\text { surowcowych }\end{array}$ & & \\
\hline & przyrodniczych & ochrona krajobrazu & & \\
\hline & & miejsce rekreacji i wypoczynku & & \\
\hline
\end{tabular}

Źródło: opracowanie własne. 
Aktywizacja zasobów kapitałowych umożliwia rozbudowę działalności istniejących przedsiębiorstw, a także lokalizację nowych inwestycji - o funkcjach: podstawowych, komplementarnych, standardowych i lokalnych - które dynamizują wielkość rynku pracy i wpływają na jego jakość.

Ważną kategorią zasobów są również zasoby finansowe ludności i przedsiębiorstw ${ }^{4}$. Podstawowe znaczenie mają zyski przedsiębiorstw, które mogą być lokowane na terenie danego układu przestrzennego lub transferowane do otoczenia. Dla układów przestrzennych korzystnym zjawiskiem jest lokowanie ich na terenie danego układu, co przyczynia się do wzrostu działalności inwestycyjnej oraz zwiększania rozmiarów rynków pracy na tym obszarze. Następnie wpływa to na wzrost dochodów gospodarstw domowych, które mogą być przeznaczane na zwiększenie konsumpcji, działalność inwestycyjną lub zwiększają oszczędności.

Na kierunki te oddziałuje określona polityka państwa, która - dzięki stosowanym instrumentom finansowym - może prowadzić do zwiększenia rozmiarów konsumpcji, np. przez obniżanie stóp procentowych i cen oraz zmniejszanie podatków pośrednich. Na zainteresowanie oszczędnościami wpływa wysokość stóp procentowych, zwłaszcza oferowanych dla lokat długoterminowych. Rosnące stopy skłaniają gospodarstwa domowe do oszczędzania, natomiast ich spadek skłania do zwiększenia konsumpcji. Na ten stan rzeczy poważny wpływ ma także sytuacja polityczna w kraju, w Europie i na świecie. Jej niepewność oddziałuje na wzrost oszczędności przedsiębiorstw i gospodarstw domowych lub ich transfer zagranicę. W warunkach stabilizacji gospodarczej ważnym zagadnieniem jest aktywizacja istniejących zasobów finansowych, które mogą pobudzić działalność inwestycyjną i konsumencką, uaktywniając w ten sposób rynek.

Aktywizacja gospodarcza układów przestrzennych prowadzi do przebudowy ich struktur społecznych i kulturowych, przyspiesza wdrażanie nowych wzorców zachowań cywilizacyjnych, a także przyczynia się do podnoszenia walorów zasobów przyrodniczych.

Przebudowa struktur społecznych i kulturowych, dzięki wdrażaniu nowych wzorców zachowań cywilizacyjnych skutkuje, zwiększeniem atrakcyjności układu przestrzennego dla generowania rozwoju, w oparciu o czynniki endogeniczne oraz przez napływ zewnętrznych czynników rozwoju. Uaktywnia to bardzo ważny proces społeczny prowadzący do podnoszenia aspiracji społecznych, przyspieszających rozwój zasobów intelektualnych oraz kapitału ludzkiego i społecznego. W konsekwencji rozwijają się ambitniejsze potrzeby edukacyjne i kulturowe, które wpływają na bardziej efektywne i kształcące formy spędzania wolnego czasu.

Społeczeństwo o odpowiednim poziomie intelektualnym i moralnym bardziej racjonalnie traktuje zasoby przyrodnicze, wykorzystuje je efektywniej, jednocześnie zwracając uwagę na ochronę środowiska, tak aby było ono odpowiednim miejscem rekreacji i wypoczynku.

\footnotetext{
${ }^{4}$ W latach 2005-2014 depozyty gospodarstw domowych wzrosły z 204,0 mld zł do 591,8 mld zł, a wartość kredytów ze 115,7 mld zł do 593,1 mld zł. Wysoka wartość depozytów bankowych wynika z rezygnacji społeczeństwa $w$ inwestowanie w ryzykowne produkty finansowych na rzecz niskooprocentowanych depozytów bieżących, wzrostu zainteresowania depozytami terminowymi oraz rosnącej skłonności do oszczędzania (M. Sajewicz, Mocny wzrost depozytów gospodarstw domowych. Rzeczpospolita, 15 stycznia 2015 r.). Tendencje do oszczędzania związane są także ze zmieniającą się sytuacją ekonomiczną kraju i świata oraz większą dbałością społeczeństwa o zabezpieczenia na wypadek nasilającego się kryzysu. Towarzyszy temu zwiększenie liczby zaciąganych kredytów. Jeżeli wzrost kredytów mieszkaniowych należy uznać za racjonalny, ponieważ zabezpieczają możliwości lepszego funkcjonowania rodzin oraz aktywizują gospodarkę dzięki wzrostowi produkcji budowlanej, to znaczna część kredytów konsumpcyjnych jest czasem zaciągana niezbyt racjonalnie i przyczynia się do trudności w ich spłatach. Wszystko to negatywnie odbija się na sytuacji ekonomicznej gospodarstw domowych.
} 
Reasumując, należy przyjąć, że kształtowanie postaw przedsiębiorczych ma na celu nie tylko osiąganie wąskich efektów ekonomicznych działalności firm, rozpatrywanych z punktu widzenia reguł mikroekonomicznego rozwoju, lecz także zawiera w sobie relacje mezoekonomiczne, przejawiające się w dbałości o podnoszenie poziomu i jakości życia społeczeństwa danego układu przestrzennego oraz wzrost jego kultury.

\section{Uwarunkowania rozwoju przedsiębiorczości w układach przestrzennych}

Wpływ rozwoju przedsiębiorczości oraz kształtowania procesów przemian społeczno-gospodarczych i kulturowych danych układów przestrzennych w podstawowym stopniu zależy od jakości uwarunkowań zewnętrznych i wewnętrznych (ryc. 4).

Ryc. 4. Podstawowe uwarunkowania rozwoju przedsiębiorczości i kształtowanie procesów przemian społeczno-gospodarczych układów przestrzennych

\begin{tabular}{|c|c|}
\hline \multirow{4}{*}{$\begin{array}{l}\text { Uwarunkowania } \\
\text { zewnętrzne } \\
\text { ('światowe, } \\
\text { międzynarodowe) }\end{array}$} & $\begin{array}{l}\text { światowa i międzynarodowa sytuacja gospodarcza, społeczna, polityczna } \\
\text { i militarna }\end{array}$ \\
\hline & $\begin{array}{l}\text { przynależność do międzynarodowych ugrupowań: politycznych, militar- } \\
\text { nych, gospodarczych }\end{array}$ \\
\hline & stosunki gospodarcze i polityczne między krajami, w tym z sąsiadami \\
\hline & $\begin{array}{l}\text { warunki i możliwości międzynarodowych przepływów (produktów, } \\
\text { usług, surowców, kapitału, technologii, finansów, ludności, zasobów } \\
\text { pracy) }\end{array}$ \\
\hline \multirow{10}{*}{$\begin{array}{c}\text { Uwarunkowania } \\
\text { wewnętrzne } \\
\text { (krajowe, regionalne, } \\
\text { lokalne) }\end{array}$} & ustrój polityczno-społeczny \\
\hline & jakość elit politycznych (władza ustawodawcza i wykonawcza) \\
\hline & wewnętrzna sytuacja polityczna (układ sił politycznych) \\
\hline & zasady instytucjonalno-systemowe w gospodarce \\
\hline & sprawność struktur państwowo-administracyjnych \\
\hline & $\begin{array}{l}\text { rozmiary, jakość i struktura zasobów: przyrodniczych, kapitałowych, } \\
\text { ludzkich, pracy }\end{array}$ \\
\hline & poziom zagospodarowania przestrzennego kraju i regionów \\
\hline & $\begin{array}{l}\text { struktury społeczne (możliwości podnoszenia zasobów intelektualnych, } \\
\text { kapitału ludzkiego i społecznego) }\end{array}$ \\
\hline & stosunki narodowościowe \\
\hline & relacje: społeczeństwo - władza (poziom zaufania) \\
\hline
\end{tabular}

Źródło: opracowanie własne. 
W warunkach nasilających się procesów globalizacji następuje coraz silniejsze zacieśnianie powiązań zachodzących w światowej przestrzeni gospodarczej, społecznej i kulturowej. Dla rozwoju działalności gospodarczej układów przestrzennych ważne są określone uwarunkowania zewnętrzne, kształtujące się w przestrzeni światowej, a także właściwe stosunki polityczne między poszczególnymi krajami. Podstawową rolę odgrywają w nich światowe bieguny wzrostu reprezentowane przez Stany Zjednoczone, Japonię, szybko rozwijające się duże kraje skupione w grupie BRIC (Brazylia, Rosja, Indie, Chiny) oraz kraje grupy OPEC, częściowo związane z państwami islamskimi. Kształtujące się uwarunkowania wpływają na możliwości współpracy, przy zachowaniu reguł konkurencyjnych. Oddziałują one także na sytuację w państwach Unii Europejskiej i krajach Europy Wschodniej, a także wpływają na sytuację danych krajów oraz poszczególnych regionów i układów lokalnych. W zależności od jakości uwarunkowań gospodarczych kształtują się więzi społeczne i kulturowe, służące zbliżaniu społeczeństw poszczególnych krajów lub wpływające na ich izolację.

Znaczący wpływ na uwarunkowania zewnętrzne wywiera określona sytuacja polityczna, która może stwarzać warunki do współpracy i wzajemnego rozwoju, ale także do konfrontacji przejawiających się w stwarzaniu barier we współpracy gospodarczej - np. w zakresie wymiany handlowej, przepływu kapitału, innowacji - często prowadzących do pogarszania sytuacji militarnej.

Ważna jest przynależność do międzynarodowych ugrupowań gospodarczych, politycznych i militarnych, które w pewnym zakresie gwarantują korzystne warunki funkcjonowania krajów wchodzących w ich struktury.

Z punktu widzenia danego kraju ważną rolę odgrywają stosunki gospodarcze i polityczne między sąsiadującymi krajami. Pozytywne relacje wpływają na możliwości wzajemnego rozwoju, natomiast pogarszające się stosunki - na ich ograniczanie. Oddziałują one także na nasilenie międzynarodowych przepływów towarów, surowców, osiągnięć technologicznych, finansów, kapitału oraz ludności i zasobów pracy. Sytuację w tym zakresie zmieniają także światowe uwarunkowania przejawiające się w możliwości rozwoju lub prowadzące do recesji i kryzysu.

Na rozwój różnej skali układów przestrzennych wpływają także uwarunkowania wewnętrzne (krajowe, regionalne, lokalne), które stwarzają podstawę wdrażania określonych reguły rozwoju, wynikających z zasad przyjętego ustroju społeczno-politycznego. Duże znaczenia ma również jakość elit politycznych i ich zasoby intelektualne, które umożliwiają poprawną analizę zmieniającej się sytuacji i zwracanie uwagi na szanse rozwoju gospodarczego oraz podnoszenie jakości i poziomu życia społeczeństwa w zmieniających się warunkach zewnętrznych i wewnętrznych. Głównym celem działania tych elit powinna być dbałość o systematyczne dynamizowanie rozwoju oraz podnoszenie konkurencyjności gospodarki w przestrzeni europejskiej i światowej.

Jakość elit politycznych znacząco zależy od jakości społeczeństwa, które demokratycznie wybiera swoich przedstawicieli do krajowych władz centralnych i władz samorządowych, a także do parlamentu europejskiego i światowych organizacji ${ }^{5}$.

\footnotetext{
${ }^{5}$ Arystoteles określa politykę jako sztukę rządzenia państwem, traktuje ją jako filozofię rządzenia, przy czym politycy stanowią dodatek do społeczeństwa cywilnego. Za czasów filozofa polityka odnosiła się do ściśle określonego zakresu zajęć, takich jak: uczestnictwo w zgromadzeniach, naradach i wyborach, wydawanie wyroków sądowych, pełnienie funkcji publicznych. Uczestnikami demokracji ateńskiej (politykami) mogli być ludzie wolni, wykształceni, powyżej 30. roku życia, którzy osiągnęli etap dojrzałości społecznej. Demokratyczny wybór dokonywał się w oparciu o reguły konkurencji intelektualnej osób starających się o dane stanowisko (prezentowane programy), dzięki czemu wybierano osoby naj-
} 
Rozwojowi przedsiębiorczości sprzyja wewnętrzna sytuacja polityczna i współpraca elit politycznych, które powinny dążyć do realizacji podstawowego celu, jakim jest kształtowanie nowoczesnego państwa, regionu czy układu lokalnego, w nawiązaniu do współczesnych tendencji rozwoju cywilizacyjnego. Zmierzają one do budowania społeczeństwa informacyjnego, w którym bazę ekonomiczną stanowi nauka, a gospodarka opiera się na wiedzy. Przyjęcie tego kryterium integruje elity różnych orientacji politycznych, natomiast brak tak sformułowanego celu prowadzi do roztrząsania przez ich przedstawicieli mało istotnych problemów, które dzielą społeczeństwo i rodzą w nim niezgodę. Należy zaznaczyć, że na podstawie jakości elit politycznych dany kraj i społeczeństwo są także oceniane na arenie międzynarodowej, dzięki czemu umacniają lub osłabiają swój autorytet na świecie i w Europie.

Dla pobudzania rozwoju gospodarczego, społecznego i kulturowego podstawowe znaczenia ma jakość zasad instytucjonalnych, sprawność struktur państwowo-administracyjnych oraz jakość stanowionego prawa. Powinny one tworzyć stabilne warunki prowadzenia działalności gospodarczej. Na tym tle paradoksalne wydają się zmiany w systemie podatkowym, w zasadach prowadzenia działalności gospodarczej, przewlekłość procesów sądowych i in. (tab. 2) ${ }^{6}$.

Tab. 2. Największe utrudnienia w prowadzeniu działalności gospodarczej w opinii przedsiębioców

\begin{tabular}{|l|c|}
\hline \multicolumn{1}{|c|}{ Wyszczególnienie } & Udzial odpowiedzi \\
\hline Ograniczony dostęp do źródeł finansowania & 32 \\
\hline Problemy z zachowaniem płynności finansowej & 31 \\
\hline $\begin{array}{l}\text { Skomplikowane przepisy podatkowe i brak jednolitych interpretacji } \\
\text { przepisów podatkowych }\end{array}$ & 9 \\
\hline $\begin{array}{l}\text { Brak przyjaznego nastawienia urzędników administracji państwowej } \\
\text { i niezrozumienie przez nich realiów prowadzenia biznesu }\end{array}$ & 6 \\
\hline Częste zmiany prawa & 5 \\
\hline Rozbudowane obowiązki o chrakterze formalnym i dokumentacyjnym & 4 \\
\hline
\end{tabular}

Źródło: badania Tax Care i Idea Banku, październik 2012.

Ważnym zadaniem w procesie pobudzania rozwoju społeczno-gospodarczego i kulturowego jest racjonalne wykorzystanie zasobów przyrodniczych, kapitałowych, finansowych i ludzkich

lepiej przygotowane do rządzenia. Wydaje się, że współcześnie mniejszą wagę przypisuje się konkurencji intelektualnej i prezentacji programów wyborczych. Obecnie w ,programach” dominują nieracjonalne obietnice, na realizację których nigdy nie będzie odpowiednich środków. Natomiast powinny być w nich wskazane możliwości wygospodarowania środków (określenie źródeł zasilania finansowego) oraz wskazane racjonalne cele, które będą realizowane przy zachowaniu reguł efektywności gospodarowania.

${ }^{6}$ Przedsiębiorcy największych utrudnień w prowadzeniu działalności gospodarczej upatrują w ograniczonym dostępie do źródeł finansowania (32\%), zachowaniu płynności finansowej (31\%), skomplikowanych, zmieniających się i niejednolicie interpretowanych przepisach podatkowych (9\%), a także w braku przyjaznego nastawienia urzędników administracji państwowej i nierozumienia przez nich realiów prowadzenia biznesu, w częstych zmianach przepisów prawa, rozbudowywaniu obowiązków o charakterze prawnym i dokumentacyjnym (wzrost biurokracji) i in. Przykłady negatywne zawiera Czarna lista barier dla rozwoju przedsiębiorczości. 
oraz zasobów pracy, w oparciu o kryteria efektywności gospodarowania. Postawa ta umożliwia dbanie o zaopatrzenie kraju, regionów i układów lokalnych w odpowiednie elementy infrastruktury techniczno-ekonomicznej i społecznej, które znacząco przyczyniają się do podnoszenia ogólnej efektywność gospodarowania.

Prawidłową realizację zakładanych celów rozwojowych zapewniają pozytywne relacje między władzą a społeczeństwem. Zaufanie w tym zakresie musi być budowane w oparciu o efektywne działania służące podnoszeniu jakości i poziomu życia społeczeństwa, zwiększania konkurencyjności gospodarki na światowym rynku oraz wzmacniania autorytetu w układzie międzynarodowym.

Racjonalne wykorzystanie uwarunkowań wymaga systematycznego monitoringu przebiegu procesów gospodarczych, społecznych i kulturowych celem określenia możliwości rozwojowych dla kraju, układów regionalnych i lokalnych.

\section{Uwagi końcowe}

Doskonalenie metod poznawania procesu kształtowania przedsiębiorczości jako ważnego czynnika rozwoju społeczno-gospodarczego i kulturowego układów przestrzennych należy uznać za ważny oraz aktualny problem badawczy. Duże znaczenie w tym zakresie mają zarówno analiza empirycznych przykładów z różnych obszarów, jak i próby ich uogólniania przez tworzenie coraz precyzyjniejszych koncepcji modelowych, które doprowadzą do budowania teorii cząstkowych, a następnie do stworzenia ogólnej teorii kształtowania tego procesu. Obok wartości poznawczych pozwalają one na podejmowanie działań decyzyjnych celem przyspieszania i skracania dystansu rozwojowego oraz podnoszenia poziomu i jakości życia społecznego. W pracach badawczych i aplikacyjnych należy przyjąć, że poszczególne układy przestrzenne zajmują swoje miejsce w strukturze hierarchicznej od układu lokalnego do układu światowego. Zasadniczo na tempo ich rozwoju wpływają konkurencyjne podmioty gospodarze pogłębiające i poszerzające swoje rynki, dobrze funkcjonujące instytucje oraz instrumenty bezpośredniego i pośredniego oddziaływania. Podstawową rolę w tym zakresie odgrywają procesy edukacyjne pozwalające na stały wzrost potencjału intelektualnego. Dzięki temu tworzą się zasoby kapitału ludzkiego i społecznego na określonym poziomie, z których - na drodze demokratycznych zasad wyboru - kształtowane są wysokiej jakości elity władzy w różnym stopniu przygotowane do pełnienia funkcji społecznych. Procesy rozwoju w zasadniczym stopniu zależne są od społecznych postaw przedsiębiorczych, reprezentowanych głównie przez przedsiębiorców zarządzających różnymi kategoriami firm, od mikrofirm po korporacje światowe.

Procesy funkcjonowania przedsiębiorstw dokonują się w oparciu o reguły mikroekonomiczne, kształtowanie rozwoju układów przestrzennych przebiega według reguł mezoekonomicznych, a gospodarki rynkowej - na podstawie reguł makroekonomicznych. W procesie rozwoju między tymi regułami zaznaczają się określone konflikty, które powinny być minimalizowane w drodze negocjacji.

Na procesy rozwoju zasadniczo wpływają przedsiębiorcy, natomiast zadaniem polityków powinno być tworzenie jak najkorzystniejszych warunków dla pobudzania wzrostu gospodarczego i społecznego określonych układów przestrzennych. W tym celu niezmiernie ważne jest poznawanie nasilenia relacji między podmiotami gospodarczymi i instytucjami a układami przestrzennymi o różnej skali. Ich współdziałanie powinno się opierać o kryteria ekonomicznej efektywności, ale w pewnych sytuacjach - z wykorzystaniem kryteriów efektywności społecznej i kulturowej. 


\section{Literatura \\ References}

Borowiec, M. (2007). Rola szkolnictwa wyższego w podnoszeniu jakości kapitału ludzkiego. Przedsiębiorczość - Edukacja, 3, 142-151.

Bratnicki, M., Strużyna, J. (2001). Przedsiębiorczość i kapitat intelektualny. Katowice: AE.

Chojnicki, Z. (2007). Rola kapitału ludzkiego w kształtowania gospodarki opartej na wiedzy w Polsce. Przeglad Geograficzny, 3-4.

Czarna lista barier dla rozwoju przedsiębiorczości. (2014). Warszawa: Lewiatan.

Grodzicki, J. (2003). Rola kapitału ludzkiego w rozwoju gospodarki globalnej. Gdańsk: Wyd. Uniwersytetu Gdańskiego.

Kamińska, W., Heffner, K. (red.). (2010). Kapitał ludzki i społeczny w procesie rozwoju obszarów wiejskich. Studia KPZK PAN, CXXVI, Warszawa.

Klepacki, B., Gołębiewska, B. (2005). Wykształcenie rolników jako forma różnicująca sytuację gospodarstw rolnych. W: Kapitat ludzki i intelektualny jako czynnik wzrostu gospodarczego i ograniczania nierówności społecznych. Rzeszów: Mitel, Uniwersytet Rzeszowski.

Kuciński, K. (2010). Przedsiębiorczość a rozwój regionalny w Polsce. Warszawa: Wyd. Delfin.

Kudełko, J. (2005). Rozwój regionalny a konkurencyjność regionów. W: Uwarunkowania rozwoju i konkurencyjności regionów. Rzeszów: Instytut Gospodarki WSIiZ w Rzeszowie.

Kudełko, J. (2007). Rozwój społeczno-gospodarczy województwa podkarpackiego i poziom jego konkurencyjności na tle kraju. W: J. Lach, M. Borowiec, T. Rachwał (red.), Procesy transformacji spoteczno-ekonomicznych i przyrodniczych struktur przestrzennych. Kraków: Wyd. Naukowe Akademii Pedagogicznej w Krakowie.

Łukasiewicz, G. (2009). Kapitał ludzki organizacji. Pomiar i sprawozdawczość. Warszawa: Wyd. Naukowe PWN.

Malik, K. (red.). (2013). Polityka rozwoju regionów oparta na specjalizacjach inteligentnych. Studia KPZK PAN, CLV, Warszawa.

Rybak, M. (red.). (2003). Kapitał ludzki a konkurencyjność przedsiębiorstw. Warszawa: Poltext.

Szałkowski, A. (2005). Kapitał społeczny jako czynnik efektywności pracy. Praca i Zabezpieczenie Spoteczne, 11.

Świtała, J. (2007). Wpływ kapitału ludzkiego na rozwój regionalny w Polsce w kontekście gospodarki opartej na wiedzy. W: S. Pangsy-Kania, E. Okoń-Horodyńska (red.), Innowacyjność w budowaniu gospodarki wiedzy w Polsce. Warszawa: Instytut Wiedzy i Innowacji.

Wach, K. (2013). Koncepcja otoczenia dla przedsiębiorczości. Typologizacja determinant rozwoju przedsiębiorczości. W: K. Zieliński (red.), Makroekonomiczne i sektorowe uwarunkowania rozwoju przedsiębiorczości. Katowice, 91-111.

Zioło, Z., Rachwał, T. (red.). (2005). Przedsiębiorczość a współczesne wyzwania cywilizacyjne. Przedsiębiorczość - Edukacja, 1.

Zioło, Z., Rachwał, T. (red.). (2007). Rola przedsiębiorczości w aktywizacji gospodarczej. Przedsiębiorczość-Edukacja, 3.

Zioło, Z., Rachwał, T. (red.). (2008). Przedsiębiorczość a współczesne wyzwania cywilizacyjne. Przedsiębiorczość - Edukacja, 4.

Zioło, Z. (2010). Rola zasobów intelektualnych, kapitału ludzkiego i społecznego w procesach rozwoju obszarów wiejskich. W: Kapitał ludzki i społeczny w procesie rozwoju obszarów wiejskich. Studia KPZK PAN, CXXVI, Warszawa, 9-28.

Zioło, Z., Rachwał, T. (red.). (2010). Przedsiębiorczość w warunkach integracji europejskiej. Przedsiębiorczość - Edukacja, 6.

Zioło, Z., Rachwał, T. (red.). (2011). Przedsiębiorczość w warunkach globalizacji. Przedsiębiorczość - Edukacja, 7. 
Zbigniew Zioło, dr nauk przyrodniczych, dr hab. i prof. nauk ekonomicznych, Uniwersytet Pedagogiczny im. Komisji Edukacji Narodowej w Krakowie, Instytut Geografii, Zakład Przedsiębiorczości i Gospodarki Przestrzennej. Podkarpacka Szkoła Wyższa im. bł. ks. W. Findysza, Katedra Gospodarki Przestrzennej w Jaśle.

Zainteresowania badawcze: gospodarka przestrzenna, geografia ekonomiczna, polityka społeczno-gospodarcza, ekonomika i polityka rozwoju przestrzennego.

Zbigniew Zioło, ScD, PhD, Professor of Economics. Pedagogical University of Cracow, Institute of Geography, Department of Entrepreneurship and Spatial Management.

Research interests: spatial management, economic geography, socio-economic policy, economics and policy of regional development.

Adres/Address: Uniwersytet Pedagogiczny im. Komisji Edukacji Narodowej w Krakowie Instytut Geografii

Zakład Przedsiębiorczości i Gospodarki Przestrzennej

ul. Podchorążych 2

30-084 Kraków, Polska

e-mail:ziolo@up.krakow.pl 